\title{
Schools of Islamic Thought in Southeast Asia
}

\author{
Peter G. Riddell \\ Centre for Islamic Studies and Muslim-Christian Relations, London School of Theology, London, UK \\ E-mail: peter_riddell@yahoo.com
}

\begin{abstract}
Sufi thinking came to represent a theological default in Islamic Southeast Asia from the sixteenth to the eighteenth centuries. There were severe polemics at times, with reformist Sufi scholars seeking to reconcile mystical practice with the Shari a.

The nineteenth century represented a watershed for Southeast Asian Islam with the consolidation of European colonialism. Old paradigms gradually gave way to new approaches among Malay-Indonesian Muslims. There was a gradual shift away from Sufi writing, whether theosophical or reformed, towards non-Sufi modernist thought.

This process was consolidated in the twentieth century. Traditionalist scholars responded with streamlined organisations and activist policies. However, the stage came to be dominated by modernists and neo-modernists, who sought to interpret the primary sacred scriptures in terms of modern world challenges. Furthermore, Sufism itself responded with its own modernist response. At the turn of the 21 st century, radical Islamist voices raised their profile amidst social and economic turmoil.
\end{abstract}

This paper will survey the mosaic of Southeast Asian Islam over five centuries, seeking to identify different voices, ideologies and schools of thought among MalayIndonesian Muslims.

Keywords: Islam, Sufism, Aceh, Java, Sumatra, reformism, neo-modernism, modernism, traditionalism, radical Islamism

\section{Introduction}

This paper addresses diverse forms of Islamic expression in Southeast Asia. Consideration of this topic should take account of a debate at the macro level which has taken place throughout Islamic history. On one side of the debate have been conservative forces committed to giving absolute priority to a literalist interpretation of Islamic scripture and law in the formation of attitudes and policy in all areas. On the other side have been, firstly, those arguing for a prime position for human powers of reason and rational thinking in interpreting the sacred texts, most recently realised in modernising tendencies in the twentieth century. Secondly, those engaged in the spiritual quest also have been in tension with the literalists, as they typically considered a focus on matters of ritual and law to be only part of their search for knowledge of and communication with God.

In this present paper, cross-references will be made to developments beyond the region from time-to-time, but limitations in space mean that the bulk of discussion will be devoted to Southeast Asian Islamic contexts and materials.

In this present paper, cross-references will be made to developments beyond the region from time-to-time, but limitations in space mean that the bulk of discussion will be devoted to Southeast Asian Islamic contexts and materials. ${ }^{2}$

\section{The sixteenth and seventeenth Centuries: Sufism Dominant}

In order to gain an insight into the religious doctrines which were predominant in the pre-colonial Malay Muslim states, it

\footnotetext{
${ }^{1}$ This paper was presented at the symposium "Islam in Southeast Asia and China: Regional Faithlines and Faultlines in the Global Ummah", 28 November - 1 December, 2002, City University of Hong Kong.

${ }^{2}$ A full study of this subject, giving due attention to broader Muslim world developments, has been undertaken in Riddell 2001.
} 
is necessary to look closely at the Sultanate of Aceh during the sixteenth and seventeenth centuries.

Turkish archives record the presence of Acehnese pilgrims in Arabia during this time (Djajadiningrat 1911:178), and it had become common for Acehnese scholars of Islam to spend a period of their lives studying at various centres of Islamic learning in the Arabian peninsula. The earliest documented case we have of an Acehnese Malay scholar travelling to the Arab world to undertake studies of the Islamic sciences is that of Hamzah Fansuri, the great sixteenth century mystic. His date of death is a matter of considerable debate, with most scholars having proposed a date between 1590 - 1604, until Guillot and Kalus (2000) suggested on the basis of epigraphical evidence that he died in Mecca in 1527 and still lies there in the famous Bab Ma'la cemetery. ${ }^{3}$ He was initiated into the Qadiriyya Sufi Order in Arabia, and in doing so established, or perhaps continued, a tradition which many Malay religious scholars were later to follow.

Islamic theosophical doctrines relating to the nature of God and Man's relationship to the Creator were a major focal point of religious teaching and writing in Aceh during this period. Sufi schools of thought were flourishing throughout the Muslim world, and in India and Aceh various competing schools, some of which denounced the others as heretical, flourished during this period.

Hamzah Fansuri's monistic notions were enlarged upon and formed the central core of the teaching and writing of Shams al-Din al-Samatrani (d. 1630), principal Islamic religious authority (shaykh al-islam) during the rule of Acehnese Sultan Iskandar Muda (r. 1607-36). However, they were not identical in approach; Hamzah drew on Ibn al'Arabi's five grades of being between the pluriformity of creation and Absolute Unity, whereas Shams al-Din's teachings were based on a doctrine of seven grades, and were influenced by al-Burhanpuri's al-Tuhfa al-mursala ila ruh alnabi (The Gift addressed to the Prophet).

Shams al-Din initiated Sultan Iskandar Muda into the Naqshbandiyya Sufi order. This suggests the centrality of Sufi thought within the Acehnese State during this period. Furthermore, it seems that the study of Islam throughout the Sultanate during this period was oriented towards speculative theosophical doctrines which were initially expounded by Hamzah, consolidated by Shams al-Din and his followers, and were later to be condemned as heretical.

The death of Iskandar Muda in 1636 led to an about face in the religious and doctrinal orientation of the Sultanate. Shortly after the succession to power of the new Sultan, Iskandar Thani, Aceh witnessed the arrival of Nur al-Din al-Raniri (d. 1658), an Islamic scholar originating from Gujerat in India. He was appointed as shaykh al-islam under the patronage of the new Sultan.
During the next seven years, the views of Hamzah and Shams al-Din were subjected to accusations of heresy by alRaniri and others claiming to represent orthodoxy. Central to the orthodox concerns was strong opposition to the suggestion by the monistic Sufis of the individual Muslim realising his essential union with the Creator. Many Islamic scholars regarded this as heresy, and al-Raniri speaks clearly in these terms in his work Hujjat al-siddiq li-daf al-zindiq.

However, al-Raniri himself does not eschew Sufi teachings. Indeed, he himself was a Sufi, having been initiated into the Rifa iyya order and also being affiliated with the 'Aydarusiyya and Qadiriyya orders. Rather, he seeks to present what he considers as a Sufi orthodoxy, termed neoSufism by some scholars (Azra 1992).

It is important to note that the above-mentioned polemic in Aceh had occurred along similar lines in India some decades earlier. Sufis who had held sway in the Mughal court in India during the latter part of the sixteenth century fell out of favour during the reign of Jahangir (r. 1605-27), who was greatly influenced by the head of the Naqshbandi order, Ahmad Sirhindi. This latter figure, though himself a Sufi, also affirmed the distinction mentioned above between creature and Creator, and his attack on Sufis whom he considered inclined to pantheism resembled in content the stance of alRaniri.

Mention should also be made of the role of the Arabian scholarly networks in this period in stimulating a neo-Sufi reformist surge in the far corners of the Muslim world. Azra identifies al-Raniri as 'one of the most important early mujaddids in the archipelago' (Azra 1992:351). In fulfilling this role, al-Raniri was transmitting reformist pulses originating in both Arabia and India, and thereby stimulating the Islamization of the archipelago.

The main Islamic scholar to dominate the religious life of the Acehnese sultanate during the latter half of the seventeenth century was 'Abd al-Ra'uf b. Ali al-Fansuri al-Singkili (c. 1615-93). At twenty-six or twenty-seven years of age, `Abd al-Ra'uf left Aceh for Arabia to further his study of the Islamic sciences. He remained there for nineteen years studying with a range of prominent scholars, including Ahmad al-Qushashi (d. 1660) of Medina, the spiritual father of many seventeenth century Indian mystics, and his successor Ibrahim al-Kurani (d. 1690), who authorised 'Abd al-Ra'uf to establish a school of mysticism in Aceh. This school was to contribute greatly to the spread of the Shattariyya Sufi Order throughout the archipelago. During this time, he sought answers to the issues arising from the violent polemic that had filled centre stage in Aceh prior to his departure in 1642. After his return to Aceh in 1661, 'Abd al-Ra'uf wrote prolifically, and reaffirmed the reformed Sufi approach initiated by al-Raniri, emphasising the

${ }^{3}$ Cf. Braginsky 2001 for a vigorous critique of their research. 
place of the Shari'a after its neglect during the long period of dominance of Hamzah and Shams al-Din.

A work of considerable significance produced by 'Abd alRa'uf is his commentary on the Qur'an, Tarjuman alMustafid, which was written around 1675. It represents the first commentary on the whole Qur'an in Malay, though other fragments of commentary survive within other writings by early Malay Islamic scholars. Though a specialist field, Qur'anic exegesis can shed important light on the diversity of early Malay-world Islam. As we saw in our survey of the early Acehnese scholars above, non-Sufi groups were pushed to the margins of the Malay Islamic stage during the sixteenth and seventeenth centuries. However, in exegesis, this group found its voice in this early period. Here was a field of Islamic learning where Sufi approaches were not the default; on the contrary, none of the surviving evidence of Qur'anic exegetical activity from sixteenth and seventeenth century Southeast Asia gives priority to allegorical Sufi interpretation of Qur'anic verses. Exegesis thus seems to have provided one of the key channels for the transmission of non-Sufi thinking which was to assume centre stage in a later period of Malay Islamic history.

\section{The eighteenth and nineteenth Centuries: Sufism Under Challenge}

Bakar comments as follows:

\begin{abstract}
'...Sufism's greatest contribution to Malay civilization lies in shaping and crystallizing its intellectual and spiritual milieu during the later phase of the Islamisation process, from the ninth/fifteenth century until about the end of the twelfth/eighteenth century.' (Bakar 1991:259)
\end{abstract}

While the colonial powers were entrenching themselves in the Malay world, a plethora of Sufi orders were also penetrating the region and consolidating their presence. The principal orders in this regard were the Qadiriyya, Chishtiyya, Shadhiliyya, Rifa iyya, Naqshbandiyya, Shattariyya and the Ahmadiyya. However, other Islamic voices were also consolidating their presence in the region, via an extensive network of Islamic study centres, known by various names depending upon the geographical location, including madrasah, pondok and pesantren. Some of these were inclined to Sufi perspectives on the faith; a gradually increasing number were not.

\subsection{The Javanese Context}

The continuing circulation of Sufi works which were inclined to theosophical monism during the eighteenth and nineteenth centuries continued to feed a tendency towards popular mystical practice, especially in Java. These tendencies were on a collision course with the reformist thinking which was gradually penetrating the region following the early reforming activities of al-Raniri and 'Abd al-Ra'uf.

A name worthy of note in the context of Islam in central Java during the early part of the eighteenth century was Ratu Pakubuwana, the wife of the Javanese ruler Pakubuwana I. In 1729-30, barely two years before her death, she set upon sponsoring a series of pious Islamic works, including the Carita Sultan Iskandar and the Kitab Usulbiyah. There is a strongly contextualized flavour to the former work, with the Islamic tale firmly set within a Javanese context (Ricklefs 1998:40-53). The Kitab Usulbiyah came to assume extraordinary proportions; it was depicted as being so valuable that copying it would equal a thousand pilgrimages to Mecca or a thousand recitations of the Qur'an. Carrying it into battle was seen as a guarantee of victory and, indeed, the book was portrayed as having mystical powers, even to the point where it was overtly equated with sacred scripture in that it was said to contain God's words (Ricklefs 1998:62-91).

Another important figure in this period was Raden Ngabehi Yasadipura I (1729-1803). Born in Surakarta, Central Java, in 1729, he was one of the most famous writers and thinkers to emerge from Central Java. Among the works usually ascribed to Yasadipura I is the Serat Cabolek. This story encapsulates a debate which took place throughout the Muslim world over many centuries regarding the respective place of the exoteric and esoteric sciences. Haji Mutamakin, the chief protagonist of this story, paid little attention to the outward ritualistic requirements of his faith, preferring to engage in a quest to unite with God. Mutamakin's demotion of the Shari'a bounced back on him, with the result that his understanding of Sufi principles became incorrect. Thus Yasadipura I includes the clear moral in the story that the Shari'a cannot be sidelined with impunity; this was clearly a matter of ongoing debate in his environment.

Yasadipura II was the son of Yasadipura I, and served as a functionary in the Sultan's palace in Surakarta. One of his most important works for our purposes was the Sasana Sunu, written in 1825. The Sasana Sunu exhorts young members of the Javanese elite, who are the principal audience addressed by the writer, to follow the Shari'a in their daily lives. The author calls for adherence to the five pillars, obedience to the dietary laws, and abstinence from alcohol and other standard Islamic prohibitions (Kumar 1997). Thus again the issue of observance of the external precepts of Islam has arisen as an issue, and its recurrent mention in the literature of the period suggests widespread neglect of the Shari'a among eighteenth and nineteenth century Javanese society.

Another key Javanese figure of the period is Ranggawarsita (1802-73), the last of the great Court poets in the city of Surakarta. One of the most interesting among his many works is Wirid Hidayat Jati. He states at the outset of this work that the teachings were based on the four sources of the Shari'a: the Qur'an, the traditions of the Prophet, the consensus of the 
scholars and analogy. Thus from the beginning he seeks to reconcile Shari'a and the Sufi records he is transmitting. There are certain elements in this work designed to please those Muslims more concerned with the exterior (zahir) sciences: God is Creator, God is omnipotent, God is One.

However, the mystical flavour of this work is still paramount. The framework of the seven grades of being appears; the sequence of created things are presented as seven stages, with the number seven allocated the importance found in much mystical thought. Monistic resonances abound:

'The Essence of the Lord Most Holy sees through our eyes; He hears through our ears; He smells through our noses; He speaks through our tongues, He feels all feelings through using all of our senses...' (Simuh 1987:72)

\subsection{Other Regions}

Abd al-Samad al-Palimbani (ca. 1704-89) originated from the Palembang region of Sumatra. He went to Arabia to further his studies as a young man, studying with several Malay scholars based in Arabia, including Muhammad Arshad alBanjari, 'Abd al-Wahab Bugis (Nasution 1992:33), and Muhammad al-Sammani (d. 1776), the founder of Sammaniyya Sufi order. It was largely through `Abd al-Samad that the Sammaniyya came to be firmly established in Palembang and elsewhere in the archipelago (Voorhoeve 1960:92).

'Abd al-Samad's greatest contribution to Malay Islam took the form of adaptations into Malay of classical Arabic works. His magnus opus was his rendering of al-Ghazali's Ihya Ulum al-Din into Malay, which he completed in 1789 after ten years work, and which is still reprinted and used in various parts of Malaysia and Indonesia today (Johns 1987:417). `Abd al-Samad saw the great medieval writers al-Ghazali and Ibn al- Arabi as providing two complementary paths in the mystical quest, with the former leading the Sufi seeker towards knowledge of God, and the latter providing metaphysical insights into the nature of the Divine and the relationship between Creator and creation (Nasution 1992:34).

It is significant that 'Abd al-Samad provided a Malay voice focusing on more Shari'a-conscious Sufi thinking at a time that debates about radical monism were continuing to be played out in the Malay world. Indeed, 'Abd al-Samad himself criticised the speculative monist teachings of the earlier Wujudiyya stream to which Hamzah Fansuri and Shams alDin al-Samatrani had belonged. His works were to be promoted by reformist minded Malay Muslims over 100 years after his death though publishing and distribution.

Another window into Malay world Islam from the colonial period is provided by Leiden Cod. Or. 2222, a manuscript held by the library of Leiden University (Janson, Tol and Witkam 1995). This manuscript belonged to Sultan Mahmud Shah, who assumed the Acehnese throne in 1870. It provides valuable data on the activities and theological interests of
Acehnese religious scholars connected with the court just prior to the commencement of the Aceh War.

The work attributes its theological basis to the teachings of Ahmad al-Qushashi (1583-1661). The text was produced by the Shattariyya Sufi order, established in Sumatra by `Abd alRa'uf. It portrays a monistic view of the Creator and his creation and makes repeated references to the seven grades. This text provides evidence of a continuing tension between monist thought and reformed Sufism, which was to make a further upsurge of reformist thinking likely.

Discussion of the eighteenth and nineteenth century Malay world would not be complete without considering the work of Raja Ali Haji of Riau (1808-70), best known for his historical writings. In early adulthood, Raja Ali Haji came to be regarded as a religious authority, deriving from his extensive early education in the Islamic sciences and Arabic language (Osman, 1976:140). He was instrumental in recruiting many teachers of Islam from outside the region to teach in Riau, and as a result of his efforts and those of his colleagues, Riau gained a reputation as a place where orthodox Islam flourished (Andaya and Matheson 1979:110). Raja Ali Haji became a very prominent member of the Riau branch of the Naqshbandiyya Sufi order, and much of the focus within his writings was designed to urge pious living according to the precepts of Islam, and thus to promote reformed Sufism.

Raja Ali Haji was an arch conservative in his views. He portrayed his society as in an advanced state of decay, and presented the society of the prophet Muhammad as an ideal which individuals should strive to attain. He called for adherence to the Shari'a, serious study of religious literature, and obedience to established scholarship.

\subsection{The Arabian Connection: Ingredients for Reform}

In the nineteenth century the intellectual and social links between the Malay world and the Middle East were further consolidated. Students of Islam continued to travel from Southeast Asia to the Middle East. Furthermore, the century witnessed a surge in immigration to Southeast Asia from the Arab world, particularly from the Hadhramaut. Finally, Arab scholars in Arabia issued increasing numbers of long-distance legal opinions, or fatawa, on wide-ranging topics in response to enquiries received from the Malay world (Cf. Kaptein 1995 and 1997).

Such developments made a significant contribution to a gradual restructuring of Malay Islamic thinking. We have seen how Sufi thinking, both in radical monist and reformed varieties, dominated the Malay Islamic arena during the sixteenth, seventeenth and eighteenth centuries. The challenge to this status quo was to pick up momentum in the late nineteenth century and assert itself in the twentieth century.

Muhammad al-Nawawi al-Jawi (1813-97) was born in Banten in West Java, the son of a village religious official 
(penghulu). He spent his early years on the island of Java studying in various locations. In his late teens, he undertook the pilgrimage to Arabia, and stayed there initially for three years before returning to Java. He returned to Mecca to settle there permanently around 1855 . He undertook further studies in Mecca, Egypt and Syria, then established himself there as a teacher (Snouck Hurgronje 1931:268).

While he does not appear to have shared the strong antiSufi views of some of his contemporaries, neither did he present Sufi approaches to the faith as normative, as did earlier teachers in the region such as Ahmad al-Qushashi. For example, he did not actively urge his students to join Sufi orders. Though his lessons included selections from the great Sufi masters, especially al-Ghazali, he avoided those writings which were inclined to attract accusations of heterodoxy, such as the writings of the leading monists. He was thus paying due respect to the Wahhabite Arabian environment in which he found himself. A change was taking place in terms of Malay Islamic education.

Al-Nawawi wrote exclusively in Arabic, and is reputed to have produced at least ninety-nine works (Nasution 1992:424). Many are still included in the reading materials of reformist pesantrens in Indonesia (Aboebakar 1957:88). He also issued many fatawa, or legal judgements, for his Malay audience both in Mecca and in Southeast Asia.

Undoubtedly his most famous work is Marah Labid, a twovolume commentary on the Qur'an written in Arabic, which represents the second complete commentary on the Qur'an written by a Malay scholar. This work was completed in 1886 and, after receiving the sanction of scholars in Mecca and Cairo, was first published in the latter city. The fact that official sanction was obtained from religious authorities in Mecca and Cairo provides some insight into the character of this work. Both of these cities in the late nineteenth century had become dominated by reformist thinking which was taking an increasingly anti-Sufi hue.

Al-Nawawi contributed to a breaking of the Southeast Asian Sufi mould, as it were. His influence on Malay scholars returning to Southeast Asia contributed to the momentous changes which were about to take place in Southeast Asian Islam.

Da'ud ibn 'Abd Allah Patani (d. ca. 1850) was another prominent Malay scholar writing from a base in Arabia. He was born in Patani, and spent around thirty-five years studying and teaching in Mecca and Medina (Nasution 1992:203). He was a prolific writer, and many of his works, which altogether numbered at least fifty-seven (Azra 1992:522), are still widely printed and used in Southeast Asia. His writings covered wide ranging topics.

Ahmad Patani (1856-1906) was another Meccan based Patani scholar. He studied in both Cairo and Mecca, where by the mid-1880s he had risen to become supervisor of the Malay Printing Press under the Turkish authorities (Matheson and
Hooker 1988:28). He taught many Malay students in Mecca, the most famous of whom was Muhammad Yusuf (18681933), later known as Tok Kenali. Of considerable significance was his letter-based dialogue with Malay Muslims on important issues relating to the faith, a medium of communication which was to play a vital role in the spread of reformist thinking from Arabia to the Malay world.

Also worthy of note at this juncture is the significant contribution made by Arab immigrants to the Malay world. The scholar who contributed most to literature from among the Hadhrami immigrant community in the Netherlands East Indies during the nineteenth century was Sayyid 'Uthman b. 'Abd Allah b. Yahya (1822-1913). By the time of his death in Batavia Sayyid 'Uthman had written around 100 works in all, with the vast majority being in Malay (Azra 1997:252).

Sayyid Uthman encountered opposition from some Malay Muslims as a result of his vehement criticism of Sufi practice in the Malay world. He launched a highly polemical attack on the Naqshbandiyya Sufi order. In all, Sayyid 'Uthman wrote at least seven treatises on Sufism, in which he included much polemical, anti-Sufi comment. His attack centred upon the claim that the masses who joined the various orders were doing so without an adequate knowledge of the Shari'a, and this was exacerbated by the fact that the leaders of the orders themselves were lacking in knowledge about the basics of Islam (Amiq 1998:100). His view brought him into conflict with mystics among the local group of religious scholars who regarded his attacks as a threat to their position.

\subsection{Continuity and Change}

In Southeast Asia, the forces for continuity, for stability, and for maintenance of the status quo had long held sway. The various societies in the Malay world were conservative, and ruling structures and paradigms were firmly entrenched during the periods examined thus far in this paper.

In the Islamic theological arena, Sufis continued to hold centre stage during most of the eighteenth and nineteenth centuries, as had been the case during the previous two centuries. Old debates continued to be played out, especially the tension between a reformed Sufism and radical theosophical doctrines.

However, the old world familiar to Southeast Asian Muslims underwent rapid change during the nineteenth century. Colonial powers gained varying degrees of control over the daily lives of Malay Muslims, with dramatic results. Old dogmas came to be increasingly put to the test and were found wanting. As the nineteenth century closed, new solutions were sought for the new problem of external colonial domination. Furthermore, new theological approaches were explored as the dominance of a culture of continuity gave way to a new culture of change.

These dramatic changes resulting from colonialism heralded the end of the dominance of Sufism and the onset of 
a mood for theological reform. The process was still in its infancy in the last quarter of the nineteenth century. In a sense, this period represents a bridge between two eras.

\section{The twentieth Century: The Age of Reform}

\subsection{Responses to Reformism in the Malay World}

There were various manifestations of pan-Islamic ideology in the Netherlands East Indies around the turn of the twentieth century. Increasing contacts occurred between local rulers and the Ottoman Caliphate authorities in Turkey. Indonesian Muslims looked increasingly to the religious authorities in the world-wide Islamic community for guidance in their developing struggle against Dutch rule.

Modernist ideas were increasingly implanting themselves in the Malay-Indonesian world around this time. There is considerable evidence for this, and indeed the transmission was not merely to be a transferral of ideas which then developed in isolation in Southeast Asia, but rather it was to take the form of a continuing dialogue between Malay Muslims and those of the Middle East where the modernist ideas had originated.

Bluhm-Warn (1997:295ff) has tracked the dialogue between Malay Muslims and the editors of the reformist periodical al-Manar in Egypt. The Malay individuals in question wrote seeking advice and legal judgements on a range of theological issues, economic and environmental matters, technological advances, issues of current political concern such as patriotism and nationalism, and a range of other matters. Kaptein (1997) has devoted attention to a similar phenomenon between the Malay world and Mecca.

The concern of the Southeast Asian writers in addressing these issues for resolution to the Middle East demonstrates two things: firstly, the perception from Southeast Asia of authority lying in the Arab world, and secondly a confidence in seeking and obtaining support from fellow Muslims in the face of conflict with non-Muslim authorities as well as with traditional Muslim leaders.

The ongoing Middle Eastern influence upon reformist developments in Southeast Asia was reinforced by the arrival in the Malay world of Ahmad Surkati, a Sudanese who had studied in both Mecca and Medina and who came to Java in 1911 as the inspector of Islamic schools as part a scholarship program sponsored by the Ottoman authorities and available for Indonesian Muslims to study in the Middle East. Surkati had a major impact upon the developments within the modernist movement in Indonesia. He was a close associate of Ahmad Dachlan, who founded the Muhammadiyah in 1912, and indeed Surkati had a great influence upon the Muhammadiyah during its early period.

The traditional leaders of Malay society, the Sultans, were not the only group to be targeted for criticism by the young modernists, who termed themselves the Kaum Muda (Young
Generation). They also directed strong and sustained criticism towards the Kaum Tua (Old Generation) traditionalists who appeared to them to protect and defend unquestioningly the domination of conservative religious scholars in the sphere of Islamic worship and belief. The local journal al-Ikhwan, a mouthpiece of the Kaum Muda, commented in 1929:

'The Kaum Tua behave as if it were necessary to accept every single word of the writings of the Ulama, as if they were equal to the Qur'an ... while the Kaum Muda consider that the Qur'an and Hadith alone have this authority, that no Ulama is infallible, and that God provided us with reason and intelligence to enable us to critically examine the statements of the Ulama.' (De Beer 1983-84:45)

A region which deserves special mention in the context of modernist reformism is the Minangkabau area of Sumatra. This region had long served as a channel for new ideas coming from the Middle East into the Malay world. A number of leading Minang scholars based themselves in Mecca, such as Shaykh Ahmad Khatib (1852-1916), and exerted the kind of influence on visiting Malay students as we saw earlier with Muhammad al-Nawawi. Ahmad Khatib, who held the position of Shafi'i Imam at the Great Mosque in Mecca (Roff 1994:60), was outspoken in criticising Sufi orders, such as the Naqshbandiyya, which he accused of being a source of pantheism. He also attacked features of Minang customary law which he considered as unislamic, such as the inheritance law within the matrilineal structure of Minang society (Djamal 1998:6ff). Furthermore, Ahmad Khatib's students went on to make profound contributions to the change in the Islamic intellectual dialogue in Southeast Asia, such as the Minangkabau scholar Shaykh Mohammed Tahir bin Jalaluddin Al-Azhari (1869-1957)

The spirit for change attained its most perceptible realisation after the Second World War, when the colonies of the Malay-Indonesian world were transformed into the independent nations of Indonesia, Malaya/Malaysia and Singapore. The pre-independence nationalist movements were then faced with the task of translating ideologies into structures of state, and several features are worthy of note at this juncture.

First, in contrast with efforts to break the link between ethnicity and religion by earlier modernist thinkers, Malaya, then Malaysia, enshrined this link in its 1957 constitution. Second, the post-independence period witnessed ongoing rivalry between traditionalists and modernists in seeking to hold the centre of the Islamic stage. In the Malaysian context this was played out by the tension between the Parti Islam SeMalaysia and the United Malay Nationalist Organisation, while in Indonesia the principal actors were the Nahdatul Ulama and the Muhammadiyah.

Furthermore, the second half of the twentieth century witnessed the evolution of neo-modernist Islamic thinking in Malaysia and Indonesia. Early signs of this were reflected in 
the struggle by some Indonesian Muslims, supported by Indonesian non-Muslim leaders, in favour of establishing the principle of an officially multi-religious state, arguing against the priority of Islam. This is most clearly seen in the Pancasila concept developed by Sukarno in 1945 and established as the philosophy of the Indonesian State.

Thus the old world was gradually being swept away by the new modes of Islamic thinking. Traditional authority structures were being challenged, as was the right of Sufi approaches to hold centre stage on the Malay theological arena. The Sufi star had set, because 'Sufism, particularly among modernist Muslims, [had come to be] regarded as one of the main causes of regression of the Muslim world' (Azra 1992:549)

\subsection{A Typology of Muslim Responses to the Modern World}

A typology of Islamic viewpoints would greatly help our goal of understanding the contemporary Islamic political scene in Southeast Asia. However, categories are subject to debate, and labels are used in different ways by different scholars. The long-established division between modernists and traditionalists has been challenged by much recent scholarship, which considers variously that three or four broad categories have emerged (Abdillah 1997:19). The materials examined for this present paper suggest a four-fold typology, which still affirms a core division between modernism and conservative traditionalism, but which adds the categories of neo-modernism and radical Islamism. Tendencies to reformist thinking are not the exclusive preserve of any single category, but rather manifest themselves within each of the four groups, as will be seen from the discussion which follows. In order to provide focus, discussion will be devoted to the Indonesian context.

\subsubsection{The Neo-Modernists}

The first stream of Islamic thought which we will consider is that of Neo-Modernism. This stream emerged in Indonesia in the late 1960s and 1970s, with its leaders drawn from graduates of the traditionalist pesantren or madrasah schools (Barton 1997:328). Jalaluddin Rakhmat, a leading Indonesian scholar of Islam, points to certain specific viewpoints shared by Indonesian neo-modernists. They tend not to see Islam through the lens of shari'a law, but rather in terms of universal values. These values need to be agreed by non-Muslims as well as Muslims, in the view of the neo-modernists. Furthermore, this viewpoint does not give priority to struggling within the political arena for the implementation of shari'a law as the basis of the state. Neo-modernists are more inclined towards a western-style democracy than other Muslim groups, and their public discourse gives greater emphasis to human rights and women's rights (Rakhmat
2000). On the question of scripture, the neo-modernists consider that the Qur'an and Sunnah should be open to new and evolving interpretations; Saeed (1997:287) describes their approach to the Islamic scriptures as 'sceptical', viewing the Hadith literature as important but lacking in authenticity. Overall, the neo-modernists are more concerned with the essence of Islamic teaching than its form. Thus debate over whether women should wear the hijab is not considered as important as ethical lifestyles. Neo-modernists are more positively disposed to Western liberal thought; they prioritise social and economic interests over political power and they cooperate with secular groups (Schwarz 1994:178).

Harun Nasution (1919-98) was one of the most prominent Indonesian Neo-Modernists of the twentieth century. He was born in Pematang Siantar, Sumatra, and spent periods in both Dutch and Islamic system schools before undertaking university studies in the Middle East. Dissatisfied with studies of the Islamic sciences at Al-Azhar University, Nasution transferred himself to the American University of Cairo, where he completed undergraduate studies with majors in education and sociology.

Nasution then entered the diplomatic service of the government of the newly independent Republic of Indonesia. In 1960 he returned to Cairo to undertake studies of Islamic Law. He then completed Master and Doctoral degrees at McGill University in Canada, with a dissertation focusing upon rational thought in the writings of Muhammad 'Abduh.

The remainder of his working life was spent with the IAIN Syarif Hidayatullah in Jakarta, where he served as Dean of the Graduate School and as Rector. Under his leadership, the IAIN in Jakarta developed a dynamic, modern curriculum, combining studies of the traditional Islamic sciences with subjects drawn from modern western educational models such as Sociology, Anthropology, Comparative Religion and secular Philosophy (Saeed 1999). Moreover, the curriculum at IAIN Jakarta incorporated study of streams of Islamic thought which were regarded with suspicion by many orthodox Islamic theologians, such as certain of the writings of Ibn al'Arabi and Mu'tazilite theology.

Nasution wrote prolifically, and his many books were concerned primarily with philosophy and rational thought, modernism, and the rationalist theology of the Mu tazila (cf. Martin, Woodward and Atmaja 1997). Nasution argued strongly in defence of the Mu tazila school of thought, long discredited throughout the Muslim world. In this way he demonstrated a certain measure of courage which characterised his writing throughout his long career.

Another key Neo-Modernist is Nurcholish Madjid (1939-). His early education included both government and pesantren schools, followed by undergraduate studies at the IAIN Syarif Hidayatullah in Jakarta, majoring in Arab literature. He took his $\mathrm{PhD}$ in Islamic Thought under the famous Muslim 
modernist Fazlur Rahman at the University of Chicago, Illinois, graduating in 1984.

Nurcholish spent much of the period 1975-98 teaching at various levels at IAIN Jakarta. He has had various other involvements, in recognition of his position as one of Indonesia's foremost Islamic thinkers. Arguably his most influential initiative has been his establishment in 1986 of the Paramadina Foundation (Yayasan Wakaf Paramadina), for which he is Chairman. Paramadina serves as a think-tank, issuing press statements, speeches and a range of published materials via hardcopy, audio and internet media, commenting on wide-ranging issues related to Islam and the modern world.

Nurcholish has been a prolific writer, producing various books and a vast number of published articles. Islam, Kemodernan, dan Ke-Indonesiaan (1987) represents an anthology of Nurcholish's thinking and provides an insight into his neo-modernist views. He gives support to the established modernist call for Islam to engage with modern times. However, he diverges from this modernist approach by proclaiming that this engagement should be done on the basis of the rich resources of traditional Islamic thought, rather than being founded on a dramatic latter-day reinterpretation of the sources, as was the approach of 'Abduh, Rida and their MalayIndonesian disciples. Further, he calls for the Islamic basis of the modern framework to be expressed within a national context: 'keIndonesiaan'.

Nurcholish argues for the ultimate separation of Islam and politics. His famous statement dating from 1970, 'Islam yes; Islamic party no' (Madjid 1998:285), has often been quoted, particularly after the collapse of Suharto's New Order government in May 1998. Nurcholish's statements at this time suggested that he advocated the relegation of Islam to the private domain and stood against increasing the role of Shari'a in matters of state (Tesoro 1998). This is a view which dates back to his student days, as reflected in the following statement taken from a speech in 1972:

'... the concept of 'Islamic state' is a distortion of the [properly] proportioned relationship between state and religion. The state is one of the aspects of worldly life whose dimension is rational and collective, while religion is an aspect of another kind of life whose dimension is spiritual and personal.' (Madjid 1998:294)

This attracted criticism from some modernist groups, who accuse him of being too close in his thinking to the liberal West.

\subsubsection{The Modernists}

The second stream of Islamic thought which deserves separate discussion is that of the Modernist Reformists. This group, descending from the modernist revolution in Islamic thought which emerged in Egypt at the beginning of the twentieth century, is very critical of traditionalist Islam on two counts: first, for what is seen as syncretistic practices among some traditionalists, which modernists consider to cause decay in the faith, and second, for the traditionalist penchant for taqlid or uncritical following of the dictates of religious leaders at the expense of creatively engaging with the Islamic scriptures (Barton 1997:324). Modernists tend to draw their support from urban populations, and regard Western liberal thought - and that of Muslim neo-modernists - with suspicion, as they consider the latter to risk selling out on important aspects of the faith. They are committed to consolidating Islam as a powerful political force but are committed to constitutional processes. They are often divided over the degree to which shari'a should have a place in state law.

The prominent Indonesian political figure Dr Amien Rais (1944-) serves as a late twentieth century representative of this group to supplement those figures from the earlier part of the century discussed previously. He was born in 1944, and received his school education in a Muhammadiyah school in Solo. He undertook undergraduate studies in Political Science at Universitas Gajah Mada in Yogyakarta, after which he took a $\mathrm{PhD}$ at the University of Chicago, writing his thesis on the Muslim Brotherhood in Egypt.

In spite of being a vocal critic of the New Order Government, Rais was co-opted by the Government to join the Indonesian Muslim Intellectuals Association (ICMI) in 1990. He has remained a strong supporter of the ICMI concept, and refuted the anti-ICMI critique from people such as the NeoModernist Abdurrahman Wahid in the following terms:

'... since the formation of ICMI, attacks and criticisms have been non-stop until now. In my opinion, this is a good sign. Because if ICMI came into being without any reaction from anyone, the ICMI infant could become stunted... I always say that our friends in ICMI do not need to tremble from the external attacks and criticisms, because we have to take heart from the Sunna of the Prophet...' (Rais 1995:281282)

Rais thus regarded ICMI, taking a modernist view, as an expression of scriptural truth in modern form.

Rais's power base was consolidated in 1993 when he was elected as Chairman of the Muhammadiyah. He played a key role in precipitating President Suharto's resignation in May 1998, and suggested directly to the New Order President that he step down. In explaining why he did this, Rais expressed his reasons in Islamic terms:

'I considered it as wajib kifayah (social obligation with religious implication) to speak up against what was clearly wrong. ABRI, Golkar, the other parties and the NGOs were silent. So, Bismillah (in the name of Allah) I braved myself to be the one to say it.' (Rahman 1998)

After the fall of Suharto, Rais formed the Partai Amanat Nasional (National Mandate Party), which endorsed him as its candidate for the Presidential elections of 1999.

Amien Rais has written a vast number of articles in newspapers and journals. Cakrawala Islam: Antara Cita dan 
Fakta (1987), his first book, comprises a selection of his essays which address a range of Islamic issues and challenges. These place a particular focus upon political issues and matters of state and the role of Islam in the modern world. His second volume, Tauhid Sosial: Formula Menggempur Kesenjangan (1998), appeared after Rais had been occupying the position of Chairman of Muhammadiyah for some years, and it therefore gives an invaluable insight into the thinking at the upper echelons of that organisation. The very unique title of 'Social Tauhid (Monotheism)' is Rais's own creation and represents his attempt to fuse faith with society, a goal which modernist reformists had long set themselves.

\subsubsection{The Traditionalists}

The third stream of Islamic thought is that of conservative traditionalism. Kurzman (1998:5) refers to this group as followers of 'customary Islam, characterized by the combination of regional practices and those that are shared throughout the Islamic world.' Aspects of this steam are twofold: on the one hand they include those who revere local saints, a practice which has attracted so much criticism from modernist reformists, plus diverse syncretistic practices, especially in Java (Beatty 2000:41-2). On the other they include a response to these syncretistic practices from traditionalist clerics, who urge a closer adherence to scriptural dictates, and above all obedience to established religious leadership.

On the Indonesian political stage this group finds its voice in the National Awakening Party (PKB), which was established on 23 July 1998 by prominent figures associated with the Nahdatul Ulama (NU). The primary non-political voice for orthodox traditionalism in Indonesian has long been the NU, which was established in 1926. The NU since its establishment

'had prioritised the values of the people of Indonesia rather than seeking to establish an Islamic state or instituting Islamic law in a formal way within the Indonesian state. Thus the PKB regarded the form of the unitary Republic of Indonesia as the final form' (Iskandar 1998:26).

The Chairman of the PKB, H. Matori Abdul Djalil, quoting Abdurrahman Wahid, emphasises the primary need for 'an Islamic society where Islamic values are carried out within the overall context of the Indonesian national state, rather than an Indonesian state where Islamic values could be officially recognised' (Abdul Djalil 1999). Thus Islam fits within the structure of Indonesia, rather than the reverse (as would be insisted upon by radical Islamists, discussed below).

The membership of this organisation currently stands at around thirty million (Mujiburrahman 1999:340), with the NU controlling an extensive educational system comprising 5742 pesantren, which encompasses 4114 kindergartens, 780 junior high schools, 299 senior high schools, nineteen universities and twenty-six other academic institutions (Mangkey 2000).
In spite of the history of NU traditionalism, in recent years young NU cadres have become more responsive to new ideas and the challenges of modernity. This is partly due to the increasing influence of activist non-government organisations (NGO) via the pesantren system of Islamic schools run by the NU. A particularly important NGO in this regard is the Centre for the Development of Pesantren and Society (P3M), established in 1983 by rural pesantren leaders (kiai) and NGO leaders. It establishes agreements with pesantrens, using them as a focus of community development work, and also runs regular seminars and workshops (halaqah) focusing on social issues in the context of Islamic jurisprudence (fiqh), such as the fiqh of land, the fiqh of tax, and the fiqh of just leadership (Effendi 1997). A further example of the pesantren system engaging with modernity is the Pondok Pesantren An-Nawawi in Bojonegoro, East Java where Kiai K.H Fachurrozi focuses on treating Islamic scholars (santri) suffering from mental illnesses. The healing methods represent a mix of alternative medicines and mystical practice (Kurniawan 1999).

Another body which articulates the conservative traditionalist viewpoint is the Indonesian Council of Islamic Scholars (Majelis Ulama Indonesia - MUI), which gathers together religious leaders at various levels from across the archipelago. Nevertheless, within such a body varying voices can be heard, representing the different streams of Islamic thought being examined within these pages.

\subsubsection{The Radical Islamists}

The fourth and final stream of Islamic thought which we will examine is that of the Islamists. This is the group which attracts much international media attention and is variously referred to (according to degrees of commitment) as extremist, fundamentalist, radical, or Islamist. This group may work within the democratic system but is ultimately committed to replacing such a system with Islamic structures, allocating a priority to Islamic Law, leadership by Muslims, and primacy of Islamic scriptural injunctions.

For most of the twentieth century a clearly discernible radical Islamist movement has not been a significant part of the Southeast Asian Islamic stage. This does not mean that such a phenomenon has been entirely absent. On the contrary, Islamist thinking can clearly be seen in a number of documents, such as the jihad-driven 1949 Proklamasi Negara Islam Indonesia (Proclamation of the Islamic State of Indonesia) by Kartosurwirjo, the leader of the abortive Darul Islam rebellion following the Indonesian achievement of independence from the Dutch:

'God willing, this Holy War or Revolution will continue until: the Islamic State of Indonesia emerges safe and secure, externally and internally, $100 \%$ de facto and de jure, in all of Indonesia; all forms of occupation and slavery disappear; all enemies of God, enemies of the faith and enemies of the State are driven from Indonesia; the Laws of Islam apply perfectly 
throughout the Islamic State of Indonesia.' (Sastrawiria and Wirasutisna 1955:262-263)

However, such documents have rarely exerted anything other than marginal influence on the direction of events in Muslim Southeast Asia during the twentieth century. Radical Islamists have never looked like gaining power in any Southeast Asian Muslim society. And the Islamist calls for revolution, so prevalent in the Middle East in the latter half of the twentieth century, have been absent from mainstream opposition groups such as the political party PAS in Malaysia and the social organisation Muhammadiyah in Indonesia.

However, the 1990s witnessed a discernible surge in Southeast Asian Islamist activity, particularly following the fall of President Suharto in 1998. A key name in a modern Indonesian political context is Ahmad Sumargono, who was elected to the Indonesian Parliament (DPR) in the June 1999 elections as a member of the Crescent Star Party (PBB), which put his name forward as a candidate for the October 1999 Presidential elections. Sumargono also serves as Head of the Indonesian Committee for Muslim World Solidarity (Komite Indonesia untuk Solidaritas Dunia Islam - KISDI), a body which prioritises an internationalist emphasis on world Islam, and which advocated on behalf of overseas Muslim causes and conflicts during the 1990s in the West Bank and Gaza, Bosnia, Kashmir and Algeria (Hefner 2000:109-10).

Sumargono expresses passionately the disenchantment felt by Islamists during the Suharto years in the following terms:

'During the New Order Period, an anti-Islam group was in power for twenty-four years, namely from 1966-1990. During this period, (Islamists) were marginalized and considered as fascists... Suharto at this time was also anti-Islam... Later Suharto changed. From 1993 the atmosphere was more conducive for the Islamic umma - the Bank Muamalat was established, ICMI was set up, the cabinet became light green. Nevertheless, Suharto changed not for Islam, but rather for his own political advantage' (Sumargono 1998:33).

Sumargono was imprisoned for six months during 1980 after a speech he gave which was critical of the Suharto regime. However, after the regime's change of direction to assume a more Islamic hue, Sumargono established a closer relationship with some of its most prominent figures. His rather qualified support for democracy is well reflected in a statement made to the press at the height of one of the debates which rages following Suharto's fall: 'the ideal is that if we have democracy, it should be proportional. And this means that the leader should be a Muslim' (Sumargono 1998:35).

In his private life Sumargono seeks to provide a model of strict adherence to Islamic precepts. He insists that his daughters wear hijab and forbids his children to walk in public with members of the opposite sex in pairs. Even as a member of the DPR, he still studies Qur'anic recitation and exegesis with a private Qur'an teacher. He argues that polygamy is permissible, providing it follows religious guidelines and the first wife agrees. He argues that it is a very effective mechanism for caring for widows and their children (Sumargono 1999).

Support for Islamists is gaining ground among segments of the Muslim youth in Indonesia. A young Islamist who is achieving increasing prominence, especially among student activists, is H. Muhammad Anis Matta. Born in October 1968 in Bone, South Sulawesi, Anis Matta has made a name for himself as a fiery young preacher, with his sermons achieving wide distribution in both cassette form and on the Internet. He was appointed as General Secretary of the Justice Party (Partai Keadilan) when it was established in August 1998 and lobbied against the appointment of Abdurrahman Wahid as President the following year ('M. Anis Matta' 2000), setting himself in opposition to the latter's neo-modernist views. The Justice Party was founded by youthful 'dakwah activists' (Dijk 2001:315) and insists on segregation between men and women in its party headquarters and bans handshakes between its male and female members.

Beyond the immediate political stage, radical Islamist sentiment is articulated by several groups. In March 1998 the Indonesian Muslim Students Association (Kesatuan Aksi Mahasiswa Muslim Indonesia - KAMMI) was established, and became very active organising demonstrations in subsequent years, with protests becoming increasingly intense as regional and sectarian conflicts flared in 2000. The leader of KAMMI, Fahri Hamzah, said in interview that Indonesia should be governed according to Islamic tenets, with the immediate banning of night-clubs, alcohol, and prostitution (Loveard 1998).

The late 1990s witnessed the emergence of the Ahlu Sunnah wal Jamaah Laskar Jihad, a radical group committed to conducting military jihad on behalf of Muslim communities in Indonesia which are in conflict with non-Muslim neighbours. It first emerged as a coherent group during the 1999 troubles in the Moluccas. In interview, the leader of the Laskar Jihad, Ja' far Umar Thalib, said the aim was to deploy 10,000 volunteer fighters in the Moluccas ('Who are the Laskar Jihad?' 2000). There were regular reports of massacres of Christians by Laskar Jihad fighters, as well as forced conversions to Islam and forced circumcisions between 200002. In the wake of the terrorist bombing of nightclubs in Kuta Beach, Bali, on October 12, 2002, Laskar Jihad spokesmen announced that the organisation was to be disbanded. There were reports of Laskar Jihad fighters leaving the Moluccas and Sulawesi at the time of writing.

Another group which has achieved notoriety in the early years of the 21 st century is the Jemaah Islamiyah. It was established by Surakarta-born Abdullah Achmad Sungkar in the 1970s. He recruited youthful zealots, of whom around 400 underwent training at military camps in Afghanistan established by the international radical group Al-Qa'ida, responsible for the terrorist attacks on United States targets on 
September 11, 2001. Upon Sungkar's death in 1999, leadership of Jemaah Islamiyah passed to his close friend Abu Bakar Bashir, born in 1938, in Jombang, East Java. This figure wears several hats. He heads the activist pesantren AlMukmin Ngruki, which is located in Ngruki village in Sukoharjo, some 30 kilometers east of Surakarta, and has an enrolment of some 500 students (Kartika 2002). By the early 1990s Jemaah Islamiyah had been heavily infiltrated by alQa'ida (Gunaratna 2002: 186).

Radical Islamist sentiment is also nurtured by events such as the First Indonesian Mujahidin Congress held in Yogyakarta in early August 2000. This event was attended by 5000 people, and donations were received from Muslims in Sweden, Germany and Australia. Criticism was voiced of the Turkish model of secularisation developed by Attaturk, with fears that Indonesia might go down same route. The Congress concluded with the establishment of the Indonesian Mujahidin Council (MMI), the purpose of which, according to the chairman of the Congress committee, Irfan S. Awwas, was

'ensuring that the shari'a is upheld by Muslims in Indonesia and the world... The main objective is the establishment of a khilafah or one leadership for all Muslims in the world, similar to that in the Prophet's era' (Wahyuni 2000).

The Indonesian Mujahidin Council is also headed by Abu Bakar Bashir. Also emerging from the Congress was a document called the Yogyakarta Charter, which called for amending the Indonesian constitution to make adherence to shari'a law compulsory for Indonesian Muslims.

\section{Conclusion}

Both labels and typologies are always problematic, especially if they are used as a hard-and-fast rule to categorise individuals and organisations. Rather labels should be seen as a convenient method of short-hand. The typologies built around these labels should be used to provide general guidelines in seeking to understand the complexities of various ideologies, including the faith of Islam in Southeast Asia.

We have seen that during the pre-colonial period and for much of the colonial period in Southeast Asia, Sufism occupied the centre of the regional Islamic stage. However, this does not imply uniformity. Indeed, intra-Sufi polemic during this time was as fierce as any tensions between Sufis and non-Sufi Muslims since that time.

The twentieth century witnessed the comparative marginalization of Sufism in Southeast Asia - or at least the relegation of Sufism to the grassroots level, away from the central political and administrative stage. In its place, various Islamic actors vied to fill the gap. Modernists and Traditionalists competed throughout the century in various arenas and over wide-ranging issues. They were joined as the century drew to a close by Neo-Modernists and radical Islamists. The latter group seemed to be grabbing much more of the spotlight as the 21st century got underway - though it should be noted that the attention which Islamists attracted probably belied their comparatively small numbers.

The 'schools of thought' thus presented are elusive concepts and should be referred to with care. If treated cautiously, they can help observers negotiate their way through the increasingly complex scene of Islamic Southeast Asia.

\section{References}

[1] Abdillah, M. (1997) Responses of Indonesian Muslim Intellectuals to the Concept of Democracy (1966-1993), Hamburg: Abera Publishing House.

[2] Abdul Djalil, H. Matori (1999) "Hubungan Islam dan Demokrasi”, Media Indonesia, 9 April.

[3] Aboebakar, H. (1957) Sejarah hidup K.H.A. Wahid Hasjim dan karangan tersiar. Djakarta: Panitya Buku Peringatan Alm. K. H. A. Wahid Hasjim.

[4] Amiq (1998) “Two Fatwas on Jihad Against the Dutch Colonization in Indonesia: A Prosopographical Approach to the Study of Fatwa", Studia Islamika 5/3: 77-124.

[5] Andaya, B. W. and Matheson, V. (1979) "Islamic Thought and Malay Tradition: The Writings of Raja Ali Haji of Riau", in A. Reid and D. Marr (eds.) Perceptions of the Past in South East Asia, Singapore: Heinemann, pp. 108-28.

[6] Azra, A. (1992) "The Transmission of Islamic Reformism to Indonesia: Networks of Middle Eastern and Malay-Indonesian 'Ulama' in the Seventeenth and Eighteenth Centuries" Ph.D. dissertation, Columbia University.

[7] Azra, A. (1997) "A Hadhrami Religious Scholar in Indonesia: Sayyid 'Uthman”, in U. Freitag and W. G. Clarence-Smith (eds.) Hadhrami Traders, Scholars and Statesmen in the Indian Ocean, 1750s to 1960s, Leiden: E. J. Brill, pp. 249- 63.

[8] Bakar, O. B. (1991) "Sufism in the Malay-Indonesian World", in S. H. Nasr (ed.) Islamic Spirituality II: Manifestations, London: SCM, pp. 259-89.

[9] Barton, G. (1997) "Indonesia's Nurcholish Madjid and Abdurrahman Wahid as Intellectuals", Studia Islamika, 4/1: 3475.

[10] Beatty, A. (2000) "Islamic and Non-islamic Prayer in Java", in D. Parkin and S. C. Headley (eds.) Islamic Prayer Across the Indian Ocean: Inside and Outside the Mosque, Richmond: Curzon, pp. 39-62.

[11] Bluhm-Warn, J. (1997) "Al-Manar and Ahmad Soorkattie”, in P. G. Riddell and T. Street (eds.) Islam: Essays on Scripture, Thought and Society, Leiden: E.J. Brill, pp. 295308.

[12] Braginsky, V. (2001) “On the Copy of Hamzah Fansuri’s Epitaph published by C. Guillot and L. Kalus", Archipel 62: 21 33.

[13] De Beer, P. (1983-4) "L'Islam en Malaysie", L'Afrique et L'Asie Modernes 139: 43-55.

[14] Dijk, K. van (2001) A country in despair. Indonesia between 1997 and 2000, Leiden, KITLV Press.

[15] Djajadiningrat, H. (1911) "Critisch Overzicht Van de in Maleische Werken vervatte gegevens over de Geschiedenis van 
het Soeltanaat Van Atjeh", Bijdragen tot de Taal-, Land- en Volkenkunde 65: 135-265.

[16] Djamal, M. (1998) "The Origin of the Islamic Reform Movement in Minangkabau: Life and Thought of Abdul Karim Amrullah", Studia Islamika 5/3: 1-46.

[17] Effendi, Djohan (1997) “Breaking out!”, Inside Indonesia 52, October - December.

[18] Guillot, C. and Kalus, L. (2000 ) "La stèle funéraire de Hamzah Fansuri”, Archipel 60: 3-24.

[19] Gunaratna, Rohan Inside Al Qaeda: Global Network of Terror, London: Hurst.

[20] Hefner, R. W. (2000) Civil Islam: Muslims and Democratization in Indonesia, Princeton and Oxford, Princeton University Press.

[21] Iskandar, A. M. (1998) "PKB: Politik Rahmatan lil'Alamin", in S. L. Hassan, K. Sukardiyono and D. M. H. Basri (eds.) Memilih partai Islam: Visi, Misi, dan Persepsi, Jakarta: Gema Insani.

[22] Janson, A., Tol, R. and Witkam, J. J. (eds.) (1995) Mystical Illustrations from the Teachings of Syaikh Ahmad alQusyasyi: A facsimile edition of a manuscript from Aceh (Cod. Or. 2222) in the Library of Leiden University, Leiden: INIS and Leiden University Library.

[23] Johns, A. H. (1987) "Islam in Southeast Asia", in M. Eliade (ed.), The Encyclopedia of Religion Vol. 7, New York: Macmillan Publishing Co., pp. 404-22.

[24] Kaptein, N. (1995) "Meccan Fatwas from the End of the Nineteenth Century on Indonesian Affairs", Studia Islamika 2/4: 141- 160.

[25] Kaptein, N. (1997) A Bilingual Meccan Fatwa Collection for Indonesian Muslims from the End of the Nineteenth Century, Jakarta: INIS.

[26] Kartika Bagus C. (2002) "MMI has no links with Osama”, The Jakarta Post, 22 January.

[27] Kumar, A. (1997) "Pancasila Plus, Pancasila Minus", In P. G. Riddell and T. Street (eds.) Islam: Essays on Scripture, Thought and Society, Leiden: E.J. Brill, pp. 253-76.

[28] Kurniawan, Gin (1999) "East Java 'pesantren' treats the mentally ill", The Jakarta Post, 14 November.

[29] Kurzman, C. (ed.) (1998) Liberal Islam: A Sourcebook, New York: Oxford University Press.

[30] Loveard, Dewi (1998) "Radicals want their say", Asiaweek, 19 June.

[31] "M. Anis Matta: Memperingatkan Amien Rais", Suara Hidayatullah, December 2000.

[32] Madjid, N. (1997) Islam, kemodernan dan keIndonesiaan, Bandung: Mizan.

[33] Madjid, N. (1998) "The Necessity of Renewing Islamic Thought and Reinvigorating Religious Understanding", in C. Kurzman (ed.) Liberal Islam: A Sourcebook, New York: Oxford University Press, pp. 284-94.

[34] Mangkey, J. (2000) "The Church in Indonesia: Facing New Challenges Towards a New Indonesia”. Paper presented at the Annual Conference of Kirche in Not/Ostpriesterhilfe, Königstein, http://www.sedos.org/english/JohnMangkey.htm.

[35] Martin, R. C., Woodward, M. R. and Atmaja, D. S. (1997) Defenders of Reason in Islam: Mu'tazilism from Medieval School to Modern Symbol, Oxford: Oneworld.
[36] Matheson, V. and Hooker, M. B. (1988) "Jawi Literature in Patani: The Maintenance of a Tradition", Journal of the Malaysian Branch, Royal Asiatic Society LXI/1: 1-86.

[37] Mujiburrahman (1999) "Islam and Politics in Indonesia: the political thought of Abdurrahman Wahid", Islam and Christian-Muslim Relations 10/3: 339-52.

[38] Nasution, H. et al (eds.) (1992) Ensiklopedi Islam Indonesia, Jakarta: Djambatan.

[39] Osman, M. T. (1976) "Raja Ali Haji of Riau: A figure of Transition or the last of the Classical Pujanggas?", in S. M. N. Al-Attas (eds), Bahasa Kesustraan Dan Kebudayaan Melayu: Essei-essei penghormatan kepada Pendita Za'ba Kuala Lumpur: Kementerian Kebudayaan, Belia dan Sukan Malaysia, pp. 13660.

[40] Rahman, Ahmad Faiz bin Abdul (1998) "Dr. Amien Rais on Democracy and Reform in Indonesia", BIC News, 1 August.

[41] Rais, M. A. (1987) Cakrawala Islam: antara cita dan fakta, Bandung: Mizan.

[42] Rais, M. A. (1995) "ICMI Harus Menyentuh Akar Rumput Umat”, in N. Ali-Fauzi (ed.), ICMI: Antara Status Quo dan Demokratisasi, Bandung: Mizan, pp. 281-86.

[43] Rais, M. A. (1998) Tauhid Sosial: formula menggempur kesenjangan, Bandung: Mizan.

[44] Rakhmat, Jalaluddin (2000) "Tentang Syariat, Islam Fundamentalis dan Liberal", Tempo Interaktif, 11 December.

[45] Ricklefs, M. C. (1998) The seen and unseen worlds in Java, 1726- 1749: history, literature, and Islam in the court of Pakubuwana II, St. Leonards, N.S.W: Asian Studies Association of Australia in association with Allen and Unwin.

[46] Riddell, P. G. (2001) Islam and the Malay-Indonesian World: Transmission and Responses, London: C. Hurst and Co.

[47] Roff, W. R. (1994) The Origins of Malay Nationalism, 2nd edn., Kuala Lumpur: Oxford University Press.

[48] Saeed, A. (1997) "Ijtihad and Innovation in NeoModernist Islamic Thought in Indonesia”, Islam and ChristianMuslim Relations 8/3: 279-96.

[49] Saeed, A. (1999) "Towards Religious Tolerance through Reform in Islamic Education: the Case of the State Institute of Islamic Studies of Indonesia”, Indonesia and the Malay World 27/79: 177-91.

[50] Sastrawiria, T. and Wirasutisna, H. (1955) Ensiklopedi Politik, Djakarta: Perpustakaan Perguruan Kem. P.P. Dan K.

[51] Schwarz, A. (1994) A Nation in Waiting: Indonesia in the 1990s, Sydney: Allen and Unwin.

[52] Simuh (1987) "Aspek Mistik Islam Kejawen dalam 'Wirid Hidayat Jati'", in A. R. Hasan (ed.) Warisan Intelektual Islam Indonesia, Bandung: Mizan, pp. 59-78.

[53] Snouck Hurgronje, C. (1931) Mekka in the Latter Part of the nineteenth Century, Leiden and London: E.J. Brill and Luzac.

[54] Sumargono, Ahmad (1998) "Kalau Status Quo ini Menguntungkan Islam, Mengapakan Tidak?”, Tempo Interaktif, 23 November:32-5

[55] Sumargono, Ahmad (1999) "Banyak Tokoh Gagal Mendidik Anaknya Sendiri”, Suara Hidayatullah, December

[56] Tesoro, Jose Manuel (1998) "Worldly Matters", Asiaweek, 19 June. 
[57] Voorhoeve, P. (1960) “Abd al-Samad b. `Abd Allah alPalimbani”, in The Encyclopaedia of Islam, 2nd edn. vol. I, Leiden: E.J. Brill, p. 92.

[58] Wahyuni, S. (2000) "Give Islamic 'syariah' a chance: Mujahidin leader", The Jakarta Post, 9 August.

[59] "Who are the Laskar Jihad?", BBC News, 20 June 2000 